\title{
ANALISIS SUMBER GEMPA MIKRO MELALUI DISTRIBUSI LOKASI HIPOSENTER MENGGUNAKAN METODE DOUBLE DIFFERENCE PADA LAPANGAN PANAS BUMI " $X$ "
}

\author{
Nur Isnaini Rahmaningtyas, Widya Utama, Wien Lestari \\ Departemen Teknik Geofisika, Fakultas Teknik Sipil, Perencanaan dan Kebumian, \\ Institut Teknologi Sepuluh Nopember \\ e-mail: widya@geofisika.its.ac.id; wien_lestari@geofisika.its.ac.id
}

\begin{abstract}
Abstrak. Monitoring sumber panas bumi perlu dilakukan untuk memaksimalkan kegiatan eksplorasi dan pemanfaatan sumber energi, dengan melihat adanya aktivitas yang terjadi dibawah permukaan yaitu gempa mikro. Uji lokasi pada penelitian ini menggunakan metode Double Difference yang terdiri dari 2 tahap yaitu clustering dan relokasi, hasil relokasi hiposenter gempa mikro pada lapangan panas bumi " $X$ " menunjukkan bahwa clustering terbagi menjadi 1 kelompok dengan jumlah event 260 data. Secara kuantitatif hasil dari proses relokasi hiposenter dengan metode Double Difference menghasilkan nilai eror yang jauh lebih kecil dibandingkan metode yang digunakan dalam penelitian sebelumnya yaitu Geiger Adaptive Damping. Metode Double Difference memiliki rata-rata nilai RMS eror sebesar 0.078 sedangkan, metode Geiger Adaptive Damping menghasilkan rata-rata nilai RMS eror sebesar 0.29. Secara kualitatif, hasil relokasi hiposenter terletak tepat dibawah jalur sumur pada daerah penelitian, dapat dibuktikan dengan hasil layout antara titik relokasi hiposenter dengan penampang 2D lintasan pengukuran metode Magnetotellurik pada daerah penelitian. Lintasan C,D dan E menujukkan hasil hiposenter berada pada sumur PPL-04ST, PPL-04AST, PPL-07, PPL-06, PPL-02AST, dan PPL02ST. Adanya titik relokasi hiposenter yang berada tepat dibawah jalur sumur produksi mengindikasikan adanya aktvitas pada zona tersebut seperti aliran-aliran fluida yang mengalir pada reservoir panas bumi. Maka dapat disimpulkan bahwa event gempa mikro yang terjadi merupakan akibat aktivitas-aktivitas produksi yang terjadi didalam sistem geothermal.
\end{abstract}

Kata Kunci: Double Difference; Gempa Mikro; Hiposenter; Panasbumi

\begin{abstract}
Geothermal monitoring needs to be done to maximize exploration and utilization of energy sources by observing at activities that occur below the surface, namely the existence of micro earthquakes. The location test in this study uses the Double Difference method which has the principle of pairing a relatively small distance. According to references, this location test is believed to be more accurate. Location testing using this method is carried out in 2 stages, namely clustering and relocation, the results of the microearthquake hypocenter relocation on the geothermal field " $X$ " indicate that clustering is divided into 1 group with 260 data events. Quantitatively, the results of hypocenter relocation using the Double Difference method produce error values that are much smaller than the method used in previous studies, namely Geiger Adaptive Damping. The Double Difference method has an average error $R M S$ value of 0.078 while the Geiger Adaptive Damping method produces an average error RMS value of 0.29. Qualitatively, the results of the hypocenter relocation are located just below the well path in the study area, it can be proved by the results of the layout between the hypocenter relocation point and the $2 D$ cross-section of the measurement path of the Magnetotelluric method. Pathways $C, D$ and $E$ show the results of the hypocenter in wells PPL-04ST, PPL-04AST, PPL-07, PPL-06, PPL-02AST, and PPL02ST. The presence of a hypocenter relocation point just below the line of production well indicates activity in the zone such as fluid flows flowing in the geothermal reservoir. The conclusion is the occurrence of microearthquake events is a result of production activities in the geothermal system.
\end{abstract}

Keywords: Double Differenc; Geothermal; Hypocenter; Microearthquake

\section{PENDAHULUAN}

Kebutuhan manusia akan sumber energi sangat besar. Sumber energi tersebut didapatkan melalui proses-proses eksplorasi sumber daya alam. Terdapat berbagai macam kegiatan eksplorasi yaitu eksplorasi mineral, eksplorasi minyak dan gas bumi serta yang baru-baru ini sedang digalakkan yaitu eksplorasi sumber panas bumi. Kegiatan-kegiatan eksplorasi yang dilakukan tidak hanya menghasilkan keuntungan yang besar, namun terdapat pula masalah-masalah yang disebabkan dari proses ekplorasi tersebut, misalnya kerusakan lingkungan 
hingga menyebabkan bencana seperti tanah longsor, dll. Maka dari itu perlu dilakukan monitoring terhadap kondisi bawah permukaan sebagai zona reservoir dengan dampak yang akan dihasilkan dari proses tersebut.

Tujuan dari penilitian ini adalah menganalisis sumber gempa mikro (gempa yang memiliki magnitudo $\leq 3$ SR) (Almira, 2013) dari hasil uji lokasi distribusi hiposenter, diduga berasal dari aktivitas eksplorasi minyak dan gas bumi pada lapangan sistem panas bumi " $X$ " atau gempa mikro yang berasal dari aktivitas tektonik pada lapangan panas bumi " $X$ ". Jika sumber dari gempa mikro telah teridentifikasi maka, dapat dilakukan monitoring pada lapangan panas bumi " $X$ " (Armi dkk., 2014). Metode Double Difference digunakan untuk uji lokasi distribusi hiposenter (Saputra dkk., 2019). Metode ini akan meminimalkan waktu residu dari waktu tempuh perhitungan dan hasil pengamatan pada dua event gempa bumi yang berdekatan dengan sejumlah stasiun pencatat gempa bumi yang sama. Jarak antara dua event gempa bumi tersebut harus jauh lebih kecil dibandingkan jarak dari stasiun ke episenter (Yunitasari dkk., 2019). Asumsi tersebut menunjukkan kedua event tersebut memiliki raypath yang sama. Kemudian dari hasil uji lokasi metode Double Difference akan digambarkan dalam dua dimensi dan dilayout dengan hasil pengukuran metode magnetotelurik untuk memvalidasi sumber gempa mikro tersebut.

\section{METODOLOGI}

A. Diagram Penelitian

Berikut ini merupakan diagram alir penelitian analisis sumber gempa mikro menggunakan metode Double Difference :

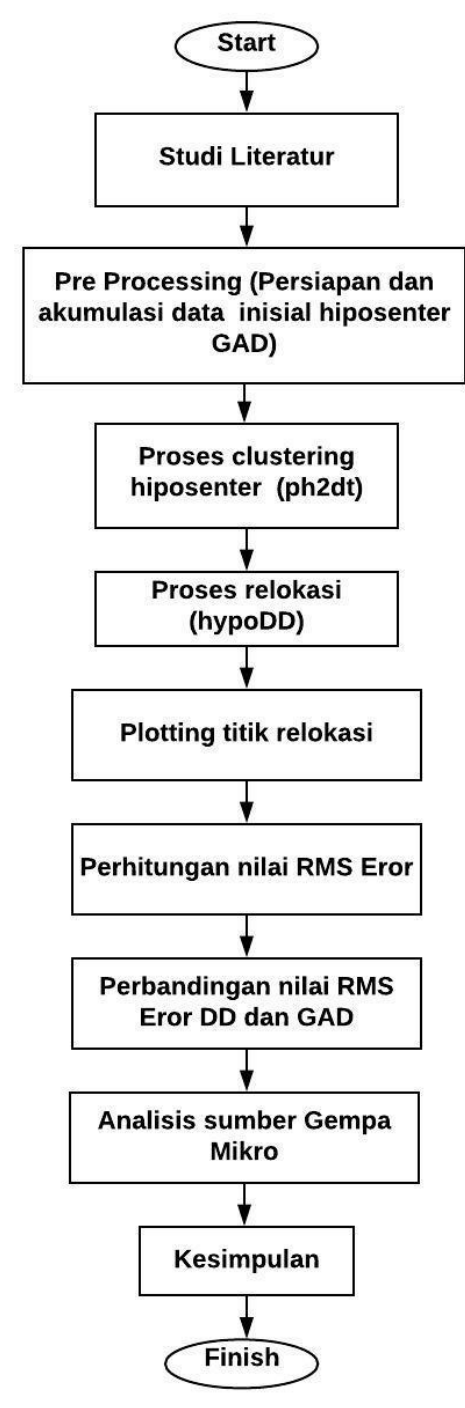

Gambar 1. Skema Kerja Output Akhir Penelitian

Data seismogram yang digunakan pada penelitian ini adalah data riil di Lapangan " $X$ " dengan format (*.msd). Kemudian dari penelitian sebelumnya digunakan metode GAD untuk mengetahui distribusi titik hiposenter awal (Gadis, 2019), dengan menggunakan model awal sesuai dengan kecepatan dan kedalaman daerah sekitar lapangan sistem panas bumi " $X$ " (Osagie dkk., 2017). Kemudian dengan menggunakan jumlah data dan waktu perekaman yang sama yaitu 90 hari, pada penelitian ini dilanjutkan dengan melakukan uji lokasi hiposenter menggunakan metode Double Difference. 
Langkah awal yaitu konversi format data, dilakukan dengan menggunakan program Python, dengan menjalankan script untuk mengubah format data dari (.txt) menjadi (.pha). Pada penelitian ini data yang diubah formatnya adalah data arrival time pada masing-masing fase yang tercatat dalam event gempa mikro. Data yang telah diubah formatnya tersebut menjadi sebuah data input ke tahapan selanjutnya, yaitu proses pengelompokkan gempa bumi (clustering) (Monteiller dkk., 2004).

Clustering dilakukan dengan mengelompokkan data gempa mikro yang terekam pada stasiun yang sama (Waldhauser dan Ellsworth, 2000). Clustering menggunakan program ph2dt memiliki parameterparameter yaitu MAXSEP merupakan jarak pengelompokkan gempa mikro dengan pasangan gempa yang ada disekitarnya, MAXDIST adalah jarak maksimum yang diperoleh antara pasangan gempa bumi dengan stasiun perekaman, dan MINLINK adalah jumlah minimum fase. Berikut contoh script yang digunakan dalam proses clustering :

" ph2dt.inp - input control file for program ph2dt

Input station file:

stasiun.dat

* Input phase file:

PTHGADTYAS2 .pha

"MINWGHT: min. pick weight allowed [0]

MAXDIST: max. distance in $\mathrm{km}$ between event pair and stations [7]

"MAXSEP: max. hypocentral separation in $\mathrm{km}$ [6]

MAXNGH: max. number of neighbors per event [31]

MMINLNK: min. number of links required to define a neighbor [7]

«MINOBS: min. number of links per pair saved [7]

XMAXOBS: max. number of links per pair saved [100]

*MAXOBS: max. number of links per pair saved [100]
*MINWGHT MAXDIST MAXSEP MAXNGH MINLNK MINOBS MAXOBS

$\begin{array}{ccccccc}\text { INWGHT } & \text { MAXDIST } & \text { MAXSEP } & \text { MAXNGH } & \text { MINLNK } & \text { MINOBS } & \text { MAXOB } \\ 0 & 20 & 15 & 10 & 8 & 8 & 100\end{array}$

Gambar 2. Script Konversi Data dalam Format (.pha)

Parameter-parameter diatas merupakan hal penting yang harus diinput dalam proses uji lokasi hiposenter menggunakan program hypoDD. Parameter-parameter ini digunakan untuk membatasi dan memperkuat solusi uji lokasi hiposenter. Hasil relokasi hiposenter dapat diplotting menggunakan Ms.Excel dalam bentuk 2 dimensi, sedangkan titik episenter hasil relokasi digambarkan dengan peta persebaran titik episenter menggunakan software ArcGIS.

\section{HASIL DAN PEMBAHASAN}

Pada pengolahan event gempa mikro sebanyak 261 data menggunakan metode Double Difference, digunakan iterasi (pengulangan) sebanyak 15 kali, jika dalam metode ini disebut Niter (Number of Iteration) dan juga digunakan yaitu Maxdist atau Dist yang mana merupakan jarak terjauh antara pasangan event dengan lokasi stasiun diberikan yaitu sebesar $20 \mathrm{~km}$, parameter maxsep atau wdct yang mana merupakan jarak terjauh antara masingmasing pasangan event diberikan jarak sebesar 15 $\mathrm{km}$ dan juga parameter minobs atau obsct yang mana merupakan jumlah minimal hubungan antar event yang tersimpan diberikan nilai sebesar 8 . Parameter-parameter diatas bisa dikatakan sebagai variabel kontrol dalam pengolahan metode Double Difference.

Hasil dari pembentukan kelompok gempa bumi atau clustering menggunakan program ph2dt menghasilkan hanya 1 kelompok gempa bumi dengan jumlah event 261 event. Pada hasil clustering tersebut menunjukkan bahwa nilai outliers sebesar $8 \%$ dan nilai weakly linked events sebesar $1 \%$. Semakin kecil nilai outliers, maka semakin baik data yang dimiliki. Begitu juga dengan nilai weakly linked events, semakin kecil nilainya maka semakin kecil pula presentase eror yang akan dihasilkan (Jannah dkk., 2016). Pada pengolahan data menggunakan hypoDD menunjukkan hasil relokasi hiposenter yang terdiri atas 1 cluster dengan jumlah event 260 karena terdapat satu event yang hilang yaitu event ke-79 yang tergabung dengan event lain dikarenakan memiliki jarak yang relatif kecil dengan event lainnya. Dalam proses running relokasi, nilai CND yang dihasilkan adalah rentang 50-70. Menurut referensi, nilai CND tersebut memenuhi range yang baik untuk menekan faktor damping, sehingga hasil relokasi bisa dikatakan stabil dengan jumlah iterasi yang diberikan (Waldhauser dan Ellsworth, 2000). Output dari pengolahan relokasi hiposenter menggunakan hypoDD, yaitu hypoDD.reloc yang merupakan hasil relokasi hiposenter, hypoDD.res yang merupakan nilai residual dari hasil relokasi yang didapatkan, dan hypoDD.sta merupakan satasiun pencatat event gempa mikro tersebut (Fathan, 2014).

Sebelum dilakukan analisa hasil relokasi gempabumi, dilakukan uji hasil relokasi dalam 
penelitian ini, yaitu pengujian distribusi frekuensi residual waktu tempuh untuk data setelah relokasi menggunakan grafik histogram pada perangkat lunak Ms. Excel (Idat dan Harmoko, 2016). Indikator hasil yang baik adalah nilai-nilai residual setelah dilakukan relokasi hiposenter menggunakan program hypoDD relatif mendekati nol. Semakin kecil nilai residual atau semakin mendekati nol maka inversi hasil perhitungan dan hasil observasi menunjukkan trend yang sama (Natania dkk., 2019). Hal ini menunjukkan bahwa relokasi hiposenter yang dilakukan menghasilkan perubahan posisi hiposenter yang lebih baik dan lebih akurat. Pada gambar 6 menunjukkan bahwa nilai residual mendekati nol sehingga dapat dikatakan bahwa pengolahan data relokasi hiposenter menggunakan hypoDD dalam peneli tian ini sudah cukup baik.

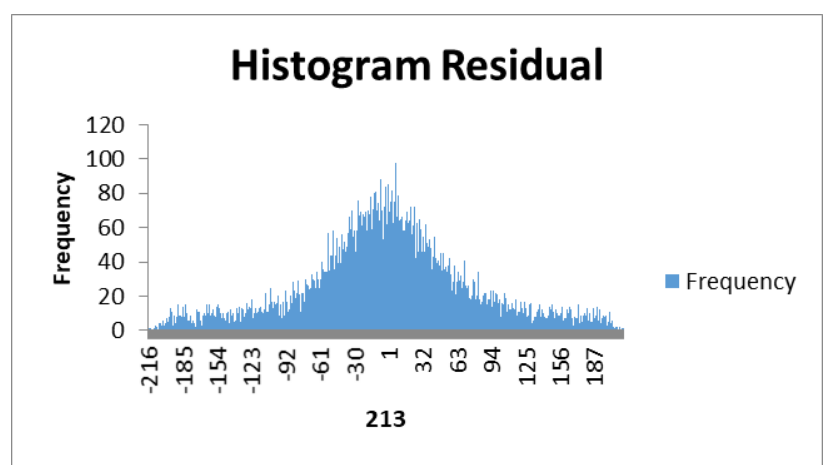

Gambar 3. Histogram Nilai Residual Relokasi Hiposenter menggunakan hypoDD

Kemudian untuk hasil relokasi yang didapatkan yaitu sejumlah 260 titik lokasi hiposenter dan nilai RMS errornya. Hasil relokasi ini akan divisualisasikan dengan plotting antara hiposenter dengan kedalamannya. Berikut akan disajikan tabel contoh 10 data hasil relokasi :

Tabel 1. Hasil Uji Lokasi dengan metode Double Difference

\begin{tabular}{|c|c|c|c|c|}
\hline No. Event & Latitude & Longitude & Depth(km) & RMS \\
\hline 1 & $-x x .175516$ & xxx.43007 & 2.288 & 0.071 \\
\hline 2 & $-x x .175912$ & xxx.429403 & 2.5 & 0.066 \\
\hline 3 & $-x x .175272$ & xxx.429606 & 2.35 & 0.068 \\
\hline 4 & $-x x .177097$ & xxx.430428 & 2.851 & 0.077 \\
\hline 5 & $-x x .176515$ & xxx.428418 & 1.685 & 0.068 \\
\hline
\end{tabular}

\begin{tabular}{|c|c|c|c|c|}
6 & $-x x .176724$ & $x x x .428011$ & 1.841 & 0.082 \\
\hline 7 & $-x x .162326$ & $x x x .434465$ & 3.088 & 0.077 \\
\hline 8 & $-x x .203209$ & $x x x .430428$ & 2.867 & 0.08 \\
\hline 9 & $-x x .178869$ & xxx.439526 & 3.442 & 0.046 \\
\hline 10 & $-x x .181837$ & xxx.423096 & 1.467 & 0.057 \\
\hline
\end{tabular}

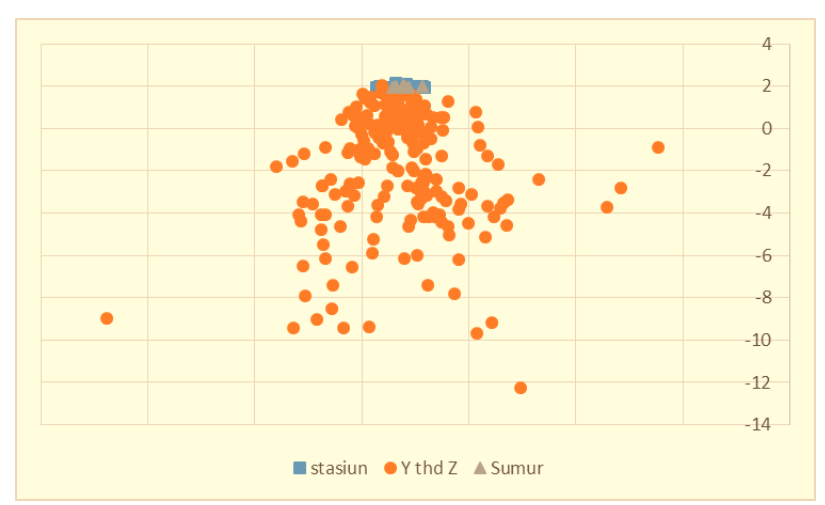

Gambar 4. Plot Hiposenter Latitude terhadap Kedalaman

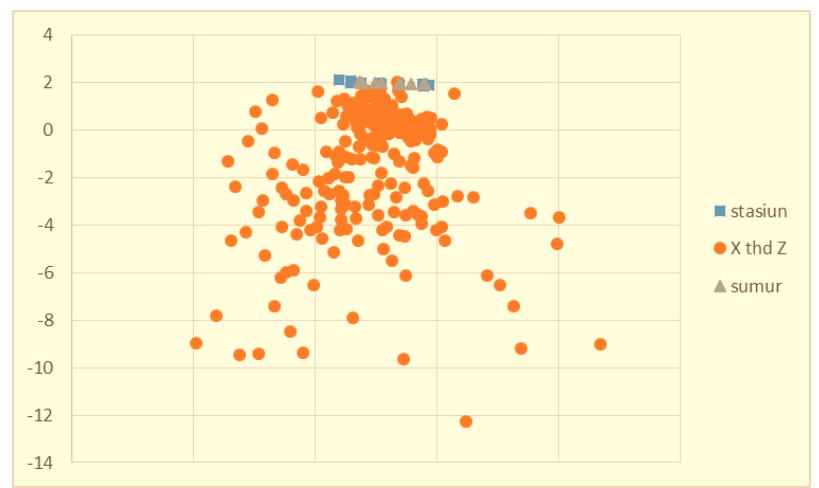

Gambar 5. Plot Hiposenter Longitude terhadap Kedalaman

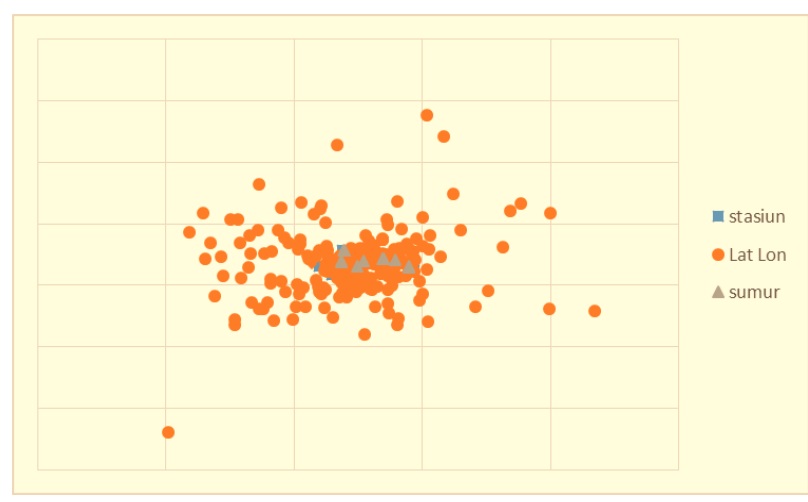

Gambar 6. Plot Hiposenter Longitude terhadap Latitude

Gambar 4 dan gambar 5 diatas menunjukkan hasil plotting antara titik latitude dan longitude 
hiposenter yang ditandai dengan bentuk bulat berwarna oren terhadap kedalamannya. Gambar kotak biru menunjukkan lokasi stasiun pengukuran pada daerah penelitian sedangkan gambar segitiga berwarna abu-abu menunjukkan lokasi sumur daerah penelitian. Pada plotting diatas memperlihatkan bahwa dominan event berada pada kedalaman range (2 hingga -2 ) km. Sedangkan gambar 6 menunjukkan hasil plotting antara longitude dan latitude. Dari semua gambar diatas penulis sengaja tidak memperlihatkan koordinat longitude dan latitude dikarenakan faktor kerahasiaan data.

Pada hasil relokasi metode Double Difference dihasilkan nilai rms (root mean square) yang merupakan hasil eror dari proses relokasi metode ini. Hasil nilai rms eror ini akan dianalisa secara kuantitatif, dengan membandingkan nilai eror metode penelitian sebelumnya dengan metode Double Difference tentunya dengan jumlah data dan waktu perekaman data yang sama. Setelah dilakukan perhitungan untuk nilai rata-rata RMS eror masing-masing metode, didapatkan metode Double Difference memiliki nilai rata-rata RMS eror sebesar 0.078 sedangkan untuk metode GAD memiliki nilai rata-rata RMS eror sebesar 0.29 (Gadis, 2019).

Dari perbandingan nilai rms eror kedua metode dengan jumlah 260 event, terbukti bahwa metode Double Difference menghasilkan nilai rms yang lebih kecil. Jika dihitung secara persentase nilai rms eror metode GAD dengan nilai rms DD (Double Difference) mengalami penurunan sebesar $73,06 \%$. Dari presentase turunnya nilai rms eror ini bisa dikatakan bahwa metode Double Difference menghasilkan titik relokasi yang lebih akurat dibandingkan penelitian sebelumnya. Nilai rms eror ini dikaitkan dengan condition number (CND) pada saat proses running relokasi, dimana nilai CND yang memengaruhi damping factor menghasilkan nilai yang memenuhi range kondisi sesuai yakni 40-80, karena apabila nilai damping sangat tinggi maka nilai CND harus diturunkan, namun jika nilai CND terlalu tinggi maka sistem Double Difference berada pada kondisi yang tidak sesuai. Selain disajikan perbandingan rms eror pada kedua metode, berikut disajikan gambar histogram perbedaan nilai rms eror secara statistik sebagai berikut :

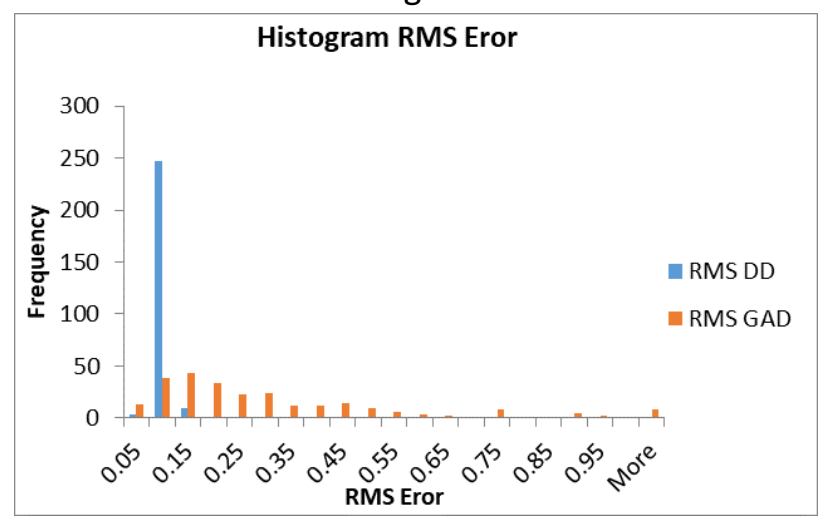

Gambar 7. Histogram Nilai RMS Eror metode GAD dan DD

Dapat dilihat dari histrogram yang dihasilkan metode Double Difference menunjukkan nilai rms eror pada range 0.05 - 0.15 sebanyak 247 data. Sedangkan pada metode Geiger Adaptive Damping (GAD) dengan range nilai rms eror yang sama hanya menunjukkan sebanyak 39 data, dan data lainnya tersebar pada range rms eror lainnya. Perhitungan secara statistik ini menunjukkan nilai rms eror pada metode Double Difference banyak terletak pada range nilai rms eror yang kecil hal ini mendukung perhitungan rata-rata nilai rms eror yang sebelumnya, sedangkan nilai rms eror pada metode GAD hampir tersebar rata di berbagai range nilai rms eror yang ada (Gadis, 2019). Selain disajikan histrogram nilai rms eror, berikut disajikan pula histogram nilai kedalaman antara metode Double Difference dan metode Geiger Adaptive Damping :

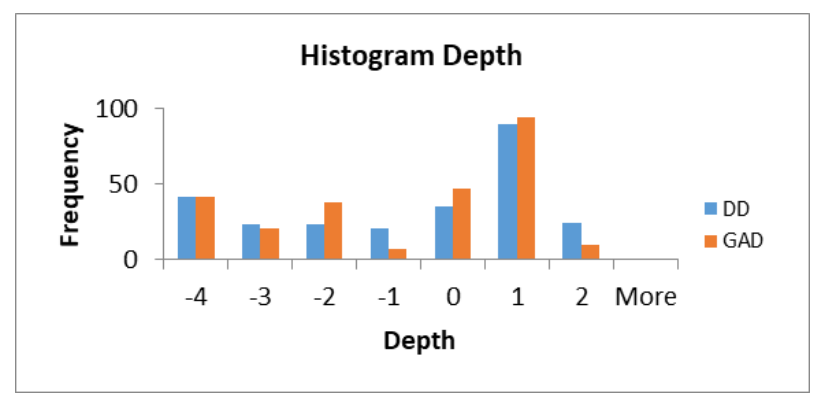

Gambar 8. Histogram Nilai Kedalaman metode GAD dan DD 
Hasil histogram kedalaman dari kedua metode ini menunjukkan nilai kedalaman yang dihasilkan dari proses relokasi hiposenter ataupun dari titik inisial hiposenter tersebar rata, sesuai dengan model kecepatan 1-D yang diberikan. Terlihat dari metode Double Difference frekuensi nilai kedalaman hampir sama dengan titik inisialnya, namun di beberapa range kedalaman jumlah event yang dihasilkan dari metode Double Difference memiliki jumlah yang lebih sedikit, hal ini sesuai dengan definisi metode ini yaitu akan dianggap hanya menjadi satu event pada raypath yang sama jika perbedaan waktu tempuh sama dan jarak antar pasang event relatif kecil.
Analisis hasil relokasi titik hiposenter akan dilakukan secara kualitatif dengan melihat datadata sekunder sebagai pendukung. Data sekunder tersebut dapat berupa model konseptual dari pengukuran secara metode geofisika yaitu magnetotelurik, keberadaan patahan geologi, posisi titik sumur pada daerah lapangan panas bumi. Titik hiposenter ini dapat menggambarkan adanya satu kejadian atau event yang terjadi dibawah permukaan bumi. Selain titik hiposenter, berikut akan disajikan gambar persebaran titik episenter dari event gempa mikro yang sudah dilakukan relokasi, sebagai berikut :

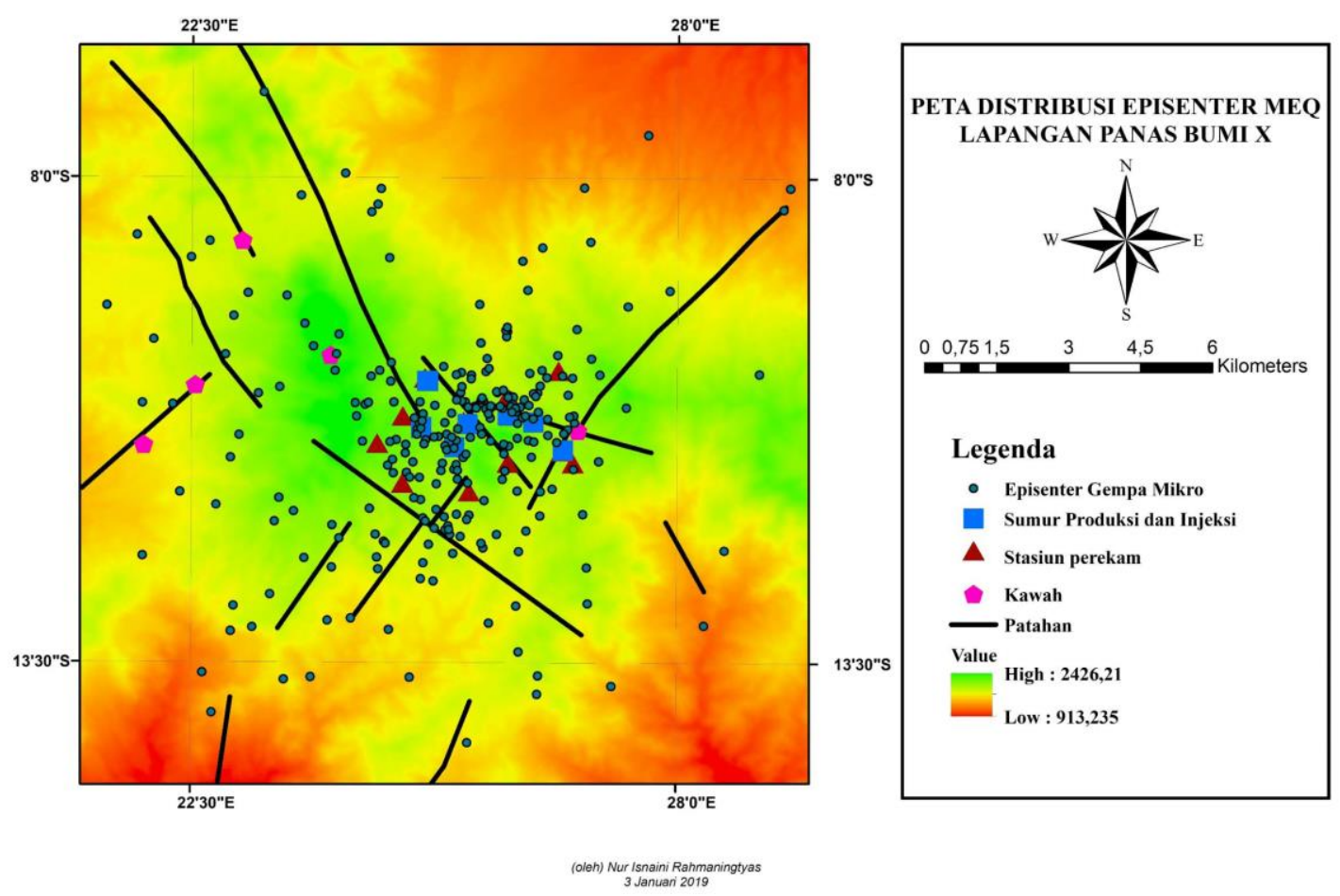

Gambar 9.Peta Distribusi Episenter MEQ

Gambar diatas menunjukkan peta persebaran titik episenter dari hasil proses relokasi metode Double Difference terhadap data titik stasiun pengukuran, patahan geologi, dan titik kawah. Pada peta diatas titik-titik episenter banyak terletak di daerah patahan geologi dan lokasi sumur produksi atau injeksi dengan kotak berwarna biru. Persebaran titik episenter menggambarkan memang benar event gempa mikro terjadi dikarenakan adanya aktivitas produksi atau aktivitas dari patahan geologi yang ada (Oktikawati dkk., 2013).

Kemudian, jika titik relokasi episenter tersebut diproyeksikan terhadap kedalaman maka disebut hiposenter (Indrastuti dkk., 2019). Titik hiposenter tersebut diplottingkan secara 2-dimensi menggunakan Ms.Excel dan untuk melihat kesesuaian dengan data pendukung yang ada maka 
dilakukan cross section penampang 2-dimensi dari hasil pengukuran metode geofisika magnetotellurik berupa penampang dari nilai resistivitas dan merupakan referensi konseptual model lapangan panas bumi daerah penelitian. Penampang resistivitas tersebut menunjukkan model konseptual panas bumi dibawah permukaan line pengukurannya. Terdapat 3 line pengukuran yaitu C,D dan E. Penampang tersebut dideskripsikan sebagai 3 zona yaitu altered clay, reservoir, dan hot source. Warna-warna pada hasil penampang pengukuran metode geofisika magnetotellurik ini adalah range nilai resistivitas yang memiliki range
(0-1000) ohm.m, semakin warna merah menunjukkan nilai resistivitas yang rendah sedangkan semakin berwarna ungu maka menunjukkan nilai resistivitas yang tinggi. Hasil penampang 2D pengukuran metode geofisika magnetotellurik ini akan dilayoutkan dengan titik hiposenter. Berdasarkan jumlahnya, titik hiposenter yang berada dalam rentang kedalaman model konseptual MT sebanyak $78.07 \%$. Rentang kedalaman tersebut berkisar antara (4000 hingga 3400) m. Berikut disajikan hasil cross section antara penampang MT dengan titik relokasi hiposenter :

Persebaran Hiposenter Gempa Bumi Mikro Terhadap Penampang 2D Lintasan C pada Pengukuran Magnetotelurik

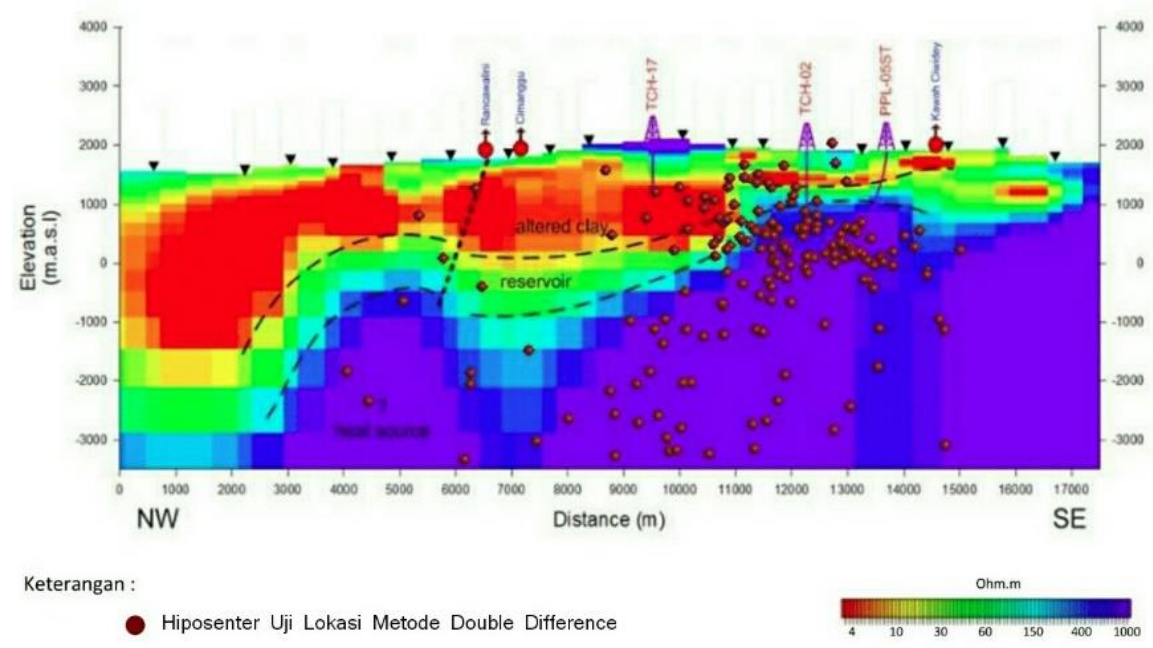

Gambar 10. Persebaran Hiposenter Gempa Bumi Mikro terhadap Penampang 2D Lintasan C

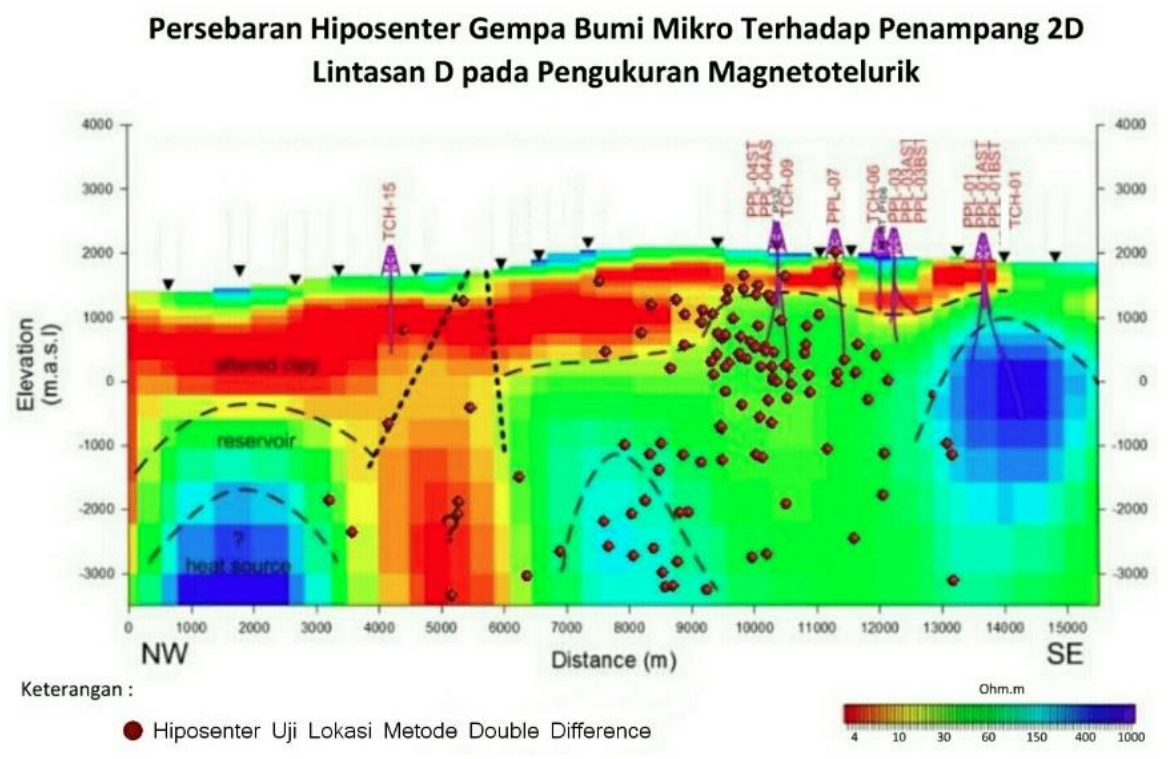


Gambar 11. Persebaran Hiposenter Gempa Bumi Mikro terhadap Pernampang 2D Lintasan D

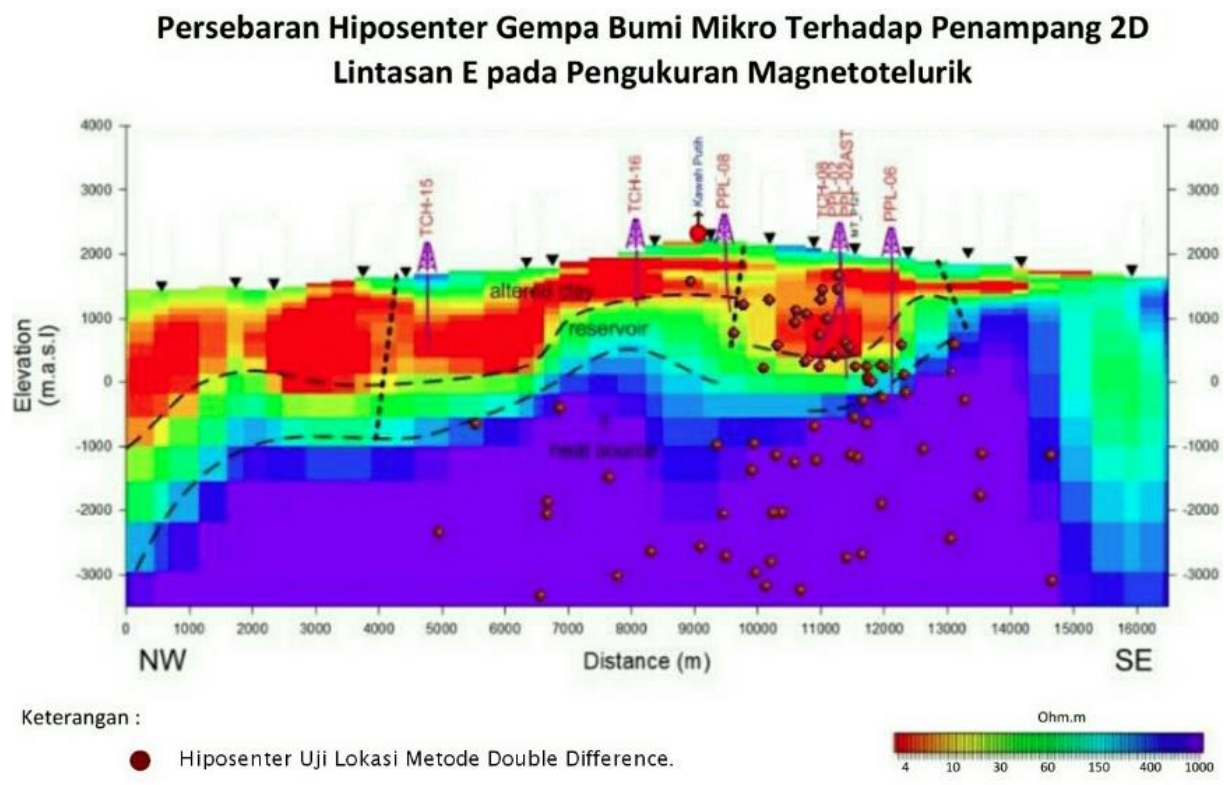

Gambar 12. Persebaran Hiposenter Gempa Bumi Mikiro terhadap Penampang 2D Lintasan E

Gambar (10 - 12) merupakan hasil layout antara titik relokasi hiposenter dengan penampang 2D lintasan pengukuran metode Magnetotellurik. Masing-masing lintasan MT menunjukkan adanya event gempa mikro yang terjadi. Pada (Gambar.10) diberikan hasil korelasi antara penampang 2D dari line pengukuran MT $C$ dengan persebaran titik hasil relokasi hiposenter menggunakan metode Double Difference (titik berwarna merah). Pada line MT C titik relokasi hiposenter mayoritas tepat berada dibawah jalur bawah sumur PPL-05ST yang merupakan sumur produksi sistem panas bumi (Angelia, 2019). Jika dilihat pada gambar, titik relokasi menyebar ditiap- tiap zona, namun pada line MT C titik relokasi hiposenter mayoritas berada pada zona heat-source dari model konseptual pengukuran metode geofisika magnetotellurik. Sedangkan pada (Gambar.11) merupakan hasil korelasi antara penampang 2D dari line $D$ dengan persebaran titik hasil relokasi hiposenter menggunakan metode Double Difference (titik berwarna merah). Pada line MT D titik relokasi hiposenter mayoritas tepat berada dibawah jalur sumur PPL-04ST, PPL04AST dan PPL-07 yang merupakan sumur produksi dari lokasi panas bumi daerah penelitian. Sedangkan pada (Gambar. 12) yakni line MT E titik relokasi hiposenter tersebar tepat berada dibawah jalur sumur PPL-06, PPL02AST dan PPL-02ST. Dimana sumur-sumur tersebut merupakan sumur produksi juga. Setelah dianalisa, hasil relokasi persebaran hiposenter menunjukkan bahwa titik hiposenter lebih banyak berkumpul di daerah lintasan magnetotellurik $\mathrm{C}$ dan $\mathrm{D}$.

Titik relokasi hiposenter yang berada tepat dibawah jalur sumur produksi mengindikasikan adanya aktvitas pada zona tersebut seperti aliranaliran fluida yang mengalir pada reservoir panas bumi. Maka dari itu, bisa disimpulkan bahwa event gempa mikro yang terjadi merupakan akibat adanya aktivitas-aktivitas produksi didalam sistem geothermal.

\section{PENUTUP}

\section{Simpulan dan Saran}

Setelah dilakukan penilitian analisis sumber gempa mikro melalui distribusi lokasi hiposenter menggunakan metode Double Difference pada lapangan panas bumi " $X$ " , maka dapat diambil beberapa kesimpulan berupa:

1. Hasil relokasi hiposenter gempa mikro pada lapangan panas bumi " $X$ " menunjukkan bahwa clustering terbagi menjadi 1 kelompok 
dengan jumlah event 260 data. Jika dihitung secara kuantitatif hasil relokasi hiposenter dengan metode Double Difference menghasilkan nilai eror yang jauh lebih kecil dibandingkan metode yang digunakan dalam penelitian sebelumnya yaitu Geiger Adaptive Damping. Dari nilai RMS eror, metode Double Difference memiliki rata-rata nilai RMS eror sebesar 0.078 sedangkan, metode Geiger Adaptive Damping menghasilkan rata-rata nilai RMS eror sebesar 0.29. Jika dihitung persentasenya, metode Double Difference dapat menurunkan persentase eror sebesar $73.06 \%$ dari nilai RMS eror metode relokasi sebelumnya. Sehingga dapat dikatakan, relokasi hiposenter menggunakan metode Double Difference memiliki nilai akurasi yang lebih tinggi. Sedangkan jika dilihat dari persebaran kedalaman dari relokasi hiposenter, hasil relokasi hiposenter tersebar rata sesuai dengan model kecepatan 1-D, dan hampir sama dengan hasil metode penelitian GAD sebelumnya.

2. Hasil analisis relokasi hiposenter secara kualitatif menunjukkan bahwa hiposenter terletak tepat dibawah jalur sumur pada daerah penelitian. Hal ini didukung pula dengan hasil layout antara titik relokasi hiposenter dengan penampang 2D lintasan pengukuran metode Magnetotellurik. Lintasan C,D dan E menujukkan hasil hiposenter berada pada sumur PPL-04ST, PPL-04AST, PPL-07, PPL-06, PPL-02AST, dan PPL02ST. Sumur-sumur tersebut merupakan sumur produksi didaerah penelitian. Adanya titik relokasi hiposenter yang berada tepat dibawah jalur sumur produksi mengindikasikan adanya aktvitas pada zona tersebut seperti aliran-aliran fluida yang mengalir pada reservoir panas bumi. Maka dari itu, bisa disimpulkan bahwa adanya event gempa mikro yang terjadi merupakan akibat adanya aktivitasaktivitas produksi didalam sistem geothermal.

Adapun saran yang diperlukan untuk mengembangkan penilitian selanjutnya, input data perlu dilakukan kembali secara runtut dan urut agar tahap pre-processing tidak memakan waktu yang sangat lama.

\section{Ucapan Terima Kasih}

Terima kasih kepada Dr. Widya Utama, DEA dan Wien Lestari, S.T, M.T. sebagai pembimbing dalam pengerjaan penilitian serta penulisan jurnal ini. Dan terima kasih kepada Orang tua penulis, rekan rekan Teknik Geofisika 2016 serta kepada seluruh elemen departemen Teknik Geofisika dalam mendukung pengerjaan tugas akhir.

\section{DAFTAR PUSTAKA}

Almira, A. (2013), PENENTUAN STRUKTUR PATAHAN DI LAPANGAN PANAS BUMI " $X$ " DENGAN MENGGUNAKAN METODE RELOKASI RELATIF KASUS GEMPA MIKRO - UPI Repository, Universitas Pendidikan Indonesia. Diambil dari http://repository.upi.edu/1934/.

Angelia, N. (2019), Penentuan Lokasi Hiposenter Gempa Bumi Mikro menggunakan Metode Geiger dengan Arrival Times P-wave dan S-wave berdasarkan S-Transform, Institut Teknologi Sepuluh Nopember, Surabaya.

Armi, R., Santosa, B.J. dan Hakim, J.A.R. (2014), RESERVOIR LAPANGAN PANASBUMI WAYANG WINDU DENGAN METODE INVERSI TOMOGRAFI DARI DATA MICROEARTHQUAKE (MEQ), Vol.1, No.1, hal. 8.

Fathan, F. (2014), Aplikasi metode double difference pada data microearthquake dengan program berbasis matlab = Application of double difference method on microearthquake data with matlab based program / Fachriza Fathan, hal. 2.

Gadis, S. (2019), Relokasi Hiposenter dan Koreksi Stasiun MEQ Lapangan Panas Bumi X menggunakan Metode Coupled Velocity-Hypocenter, Institut Teknologi Sepuluh Nopember, Surabaya.

Idat, C.F. dan Harmoko, U. (2016), "RELOKASI HIPOSENTER GEMPA MIKRO DENGAN METODE SED DAN JHD SEBAGAI ANALISIS RESERVOAR AREA PANAS BUMI-X", YOUNGSTER PHYSICS JOURNAL, Vol.5, No.3, hal. 97-104.

Indrastuti, N., Nugraha, A.D., McCausland, W.A., Hendrasto, M., Gunawan, H., Kusnandar, R., Kasbani dan Kristianto (2019), "3-D Seismic Tomographic Study of Sinabung Volcano, Northern Sumatra, Indonesia, during the InterEruptive Period October 2010-July 2013", Journal of Volcanology and Geothermal Research, Vol.382, hal. 197-209. 
http://doi.org/10.1016/j.jvolgeores.2019.03.00 1.

Jannah, I.N., Anggono, T. dan Yulianto, T. (2016), "APLIKASI METODE DOUBLE DIFFERENCE DALAM RELOKASI HIPOSENTER UNTUK MENGGAMBARKAN ZONA TRANSISI ANTARA BUSUR BANDA DAN BUSUR SUNDA", YOUNGSTER PHYSICS JOURNAL, Vol.5, No.3, hal. 113-122.

Monteiller, V., Jean-Luc, G., Virieux, J. dan Okubo, P. (2004), "Imaging Kilauea Volcano Magmatic System Using an Efficient Algorithm for DoubleDifference Tomography and Cross-Spectral Time-Delays", AGU Fall Meeting Abstracts,.

Natania, K.A., Sahara, D.P., Nugraha, A.D. dan Ramadhan, I. (2019), "The Physical Mechanisms of Geothermal Reservoir During Hydraulic Injection Through Microearthquake Tomography", Journal of Physics: Conference Series, Vol.1204, hal. 012081. http://doi.org/10.1088/17426596/1204/1/012081.

Oktikawati, A., Harmoko, U. dan Raharjo, I.B. (2013), "KARAKTERISASI CAP ROCK DAN RESERVOIR AREA GEOTERMAL $X$ BERDASARKAN STUDI SEISMISITAS DENGAN METODE SED", YOUNGSTER PHYSICS JOURNAL, Vol.2, No.3, hal. 53-58.

Osagie, A.U., Nawawi, Mohd., Khalil, A.E. dan Abdullah, K. (2017), "Regional Travel-Time Residual Studies and Station Correction from 1-D Velocity Models for Some Stations around Peninsular Malaysia and Singapore", NRIAG Journal of Astronomy and Geophysics, Vol.6, No.1, hal. 19-29. http://doi.org/10.1016/j.nrjag.2016.11.002.

Saputra, F.R.T., Syuhada, S. dan Anggono, T. (2019), "Double Difference Relocation of Earthquakes in Sunda-Banda Transition Zone, Indonesia", Journal of Physics: Conference Series, Vol.1191, hal. 012012. http://doi.org/10.1088/17426596/1191/1/012012.

Waldhauser, F. dan Ellsworth, W. (2000), "A DoubleDifference Earthquake Location Algorithm: Method and Application to the Northern Hayward Fault, California", Bulletin of the Seismological Society of America, Vol.90, hal. 1353-1368.

http://doi.org/10.1785/0120000006.

Yunitasari, I., Nugraha, A.D. dan Sule, M.R. (2019), "3D Seismic Tomography to Image the Subsurface
Structure of "IY" Geothermal Field Using Double-Difference Method and Waveform Cross-Correlation: Preliminary Results", Journal of Physics: Conference Series, Vol.1204, hal. 012095. http://doi.org/10.1088/17426596/1204/1/012095. 